\title{
Quantifying the role of chemical weathering rates on soil developed along an altitudinal transect in the mountainous environments, Turkey
}

\author{
Omar Alsalam a,*, Cevdet Şeker b, Mert Dedeoğlu b
}

a Baghdad University, Faculty of Agriculture, Department of Soil Science and Water Resources, Baghdad, Iraq

b Selçuk University, Faculty of Agriculture, Department of Soil Science and Plant Nutrition, Konya, Turkey

\section{Article Info}

Received : 21.06 .2019

Accepted : 07.02.2020

\begin{abstract}
Climate and elevations play an important role in controlling rate of weathering and soil formation. The role of chemical weathering rate on soil developed along an altitudinal transect in the mountainous environments in Turkey was investigated to determine the effects of climate on the geochemical characteristics of the soil. The main purposes of this study were: i) To characterize the geochemical characteristics of soils as a function of climate ii) To evaluate the soil formation and decomposition rates in Climosequence depending on the elevation by using geochemical data. For this purpose, four representative profiles were dug at different elevations. The transect of four soils formed in limestone elevations from 1139 to $1809 \mathrm{~m}$. Our results showed that the rate of chemical weathering of CIA, CIW, PIA and MIA indicators decreased with the increase in elevation. In contrast, WIP value increased at higher altitudes and exhibited different weathering directions by deviating from the main trend in the A-CN-K diagram that composition of weathered soils was easily influenced by the quantity of precipitation, degree of gradient and height differences. Therefore, it was concluded that the main factors determining soil development was climate and elevations, and both determine the leaching regime and weathering rates.
\end{abstract}

Keywords: Climosequence, elevations, geochemical, soil development, weathering index. (C) 2020 Federation of Eurasian Soil Science Societies. All rights reserved

\section{Introduction}

Soil development is closely associated with specific weathering intensities under special mountainous environmental conditions Baumann et al. (2014). Soil development occurs through numerous physical, biological and chemical weathering processes acting to alter the parent rock on the soil surface. The formation of soils (pedogenesis) is a process by which weathering alters constituents within the parent material through the loss of more mobile (i.e., soluble) elements, concurrent enrichment of less mobile elements Le Blond et al. (2015). It is well established that soil-pedogenesis processes result in losses, gains or redistribution of elements, and that not all elements are affected in the same way. Elements are also recycled by the forest vegetation and such recycling can play a major role in soil development and the redistribution of elements. This is mainly the case with forest ecosystems, which are very efficient at recycling major nutrients. (Barbosa et al., 2015; Rate and Sheikh-Abdullah, 2017). Geochemical-based weathering indices are commonly used to measure and compare the relative extent and intensity of soil pedogenesis based on the chemistry of the surface soils (Osat et al., 2016) and weathering indices are used for evaluating soil fertility and development, demonstrating the impact of climate on soil surface weathering (Price and Velbel, 2003; Baumann et al., 2014). Chemical weathering indices incorporate major element oxides chemistry into a single value for each sample Egli et al. (2006). Studies in the regions of altitudinal gradient characterized by decreasing temperatures and increasing rainfalls, have shown the influence of the

\footnotetext{
${ }^{*}$ Corresponding author.

Baghdad University, Faculty of Agriculture, Department of Soil Science and Water Resources, Baghdad, Iraq

Tel.: +905394332321

E-mail address: omertareq_82@yahoo.com

e-ISSN: 2147-4249

DOI: $10.18393 /$ ejss.689428
} 
climatic contrast on soil formation, studies on sequences of soils developed in contrasting climate mountainous environments may be a valuable tool to predict the influence of climate on weathering rates, soil development stage, and soil formation processes (Egli et al. 2003, 2006, 2008, 2009; Lybrand et al., 2011; Moazallahi and Farpoo,r 2012; Barbosa et al., 2015; Zhou et al., 2015; Osat et al., 2016) and provide better understanding of elemental mobility during the weathering. In this study, the soil that has different elevations in Anamas Mountain and develops on locations with different precipitation and leaching regime was examined and the geochemical characteristics of the soil was determined. The geochemical approach in which the concentrations of the major and rare earth elements are used to reveal the weathering of the soils with different climatic characteristics affected by altitude difference be permit study of the effects of various climatic combinations on soil development so that the chemical weathering rates of soils formed on a Climosequence in humid climatic conditions will be comparatively determined. The following research objectives were: i) To characterize the geochemical characteristics of soils as a function of climate and ii) To evaluate the soil formation and decomposition rates in Climosequence depending on the elevation by using geochemical data.

\section{Material and Methods}

\section{Study area}

Study area Anamaslar, Beysehir, is located within the borders of the Lakes Region. 4 different heights were determined as a result of the studies conducted in the field where the study area is located. For this purpose, 4 profiles were dug between the elevations of 1139-1809 m (Figure 1). The study area is between the coordinates (Table 1). All profiles had limestone primary material and forest vegetation. The profiles were all steep. Profile 4 had the highest slope ( $>45$ ) and other profiles had a slope of 30-45 (Table 1). The Anamas Mountains are generally composed of Jurassic-Cretaceous aged limestones in the second time. The Triassic sandstone, claystone and conglomerates and the Triassic limestones and dolomites are observed at the foot of the Anamas Mountains. According to the meteorological station data in the region, the average annual precipitation from 1960 to 2017 was $546.4 \mathrm{~mm}$, the annual evaporation was $1248.1 \mathrm{~mm}$, the average annual temperature was $12 .{ }^{\circ} \mathrm{C}$, and the average soil temperature in $50 \mathrm{~cm}$ was $14.6{ }^{\circ} \mathrm{C}$. According to the prepared rainfall-evaporation-temperature because of these data, the temperature regime of the region is mesic and the moisture regime is xeric (USDA, 2014) (Figure 2).
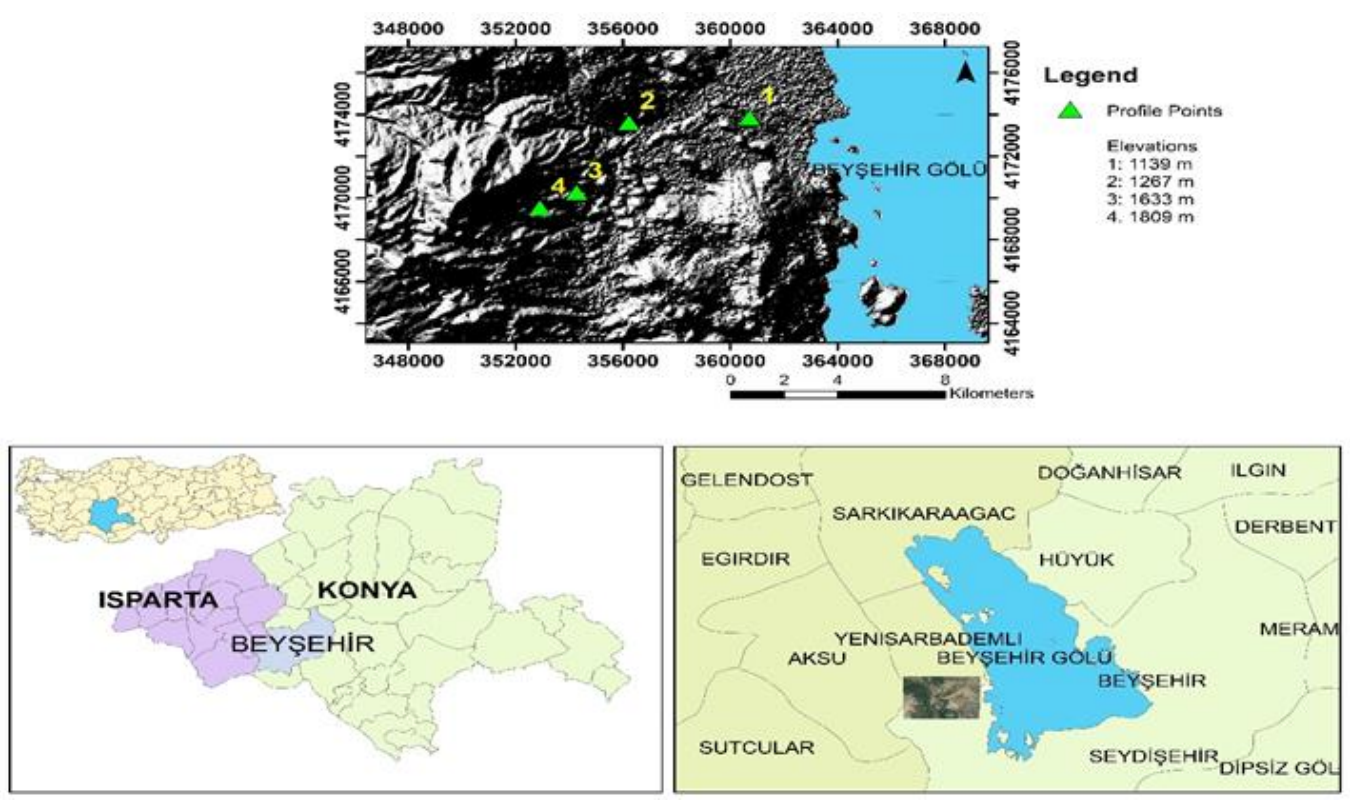

Figure 1. Location map of the study area that shows general transect of the four profiles

\section{Soil sampling and analysis}

Elevation is an important factor affecting the climate and could provide insight into the impact of climate on soil processes through affecting the type and rates of geochemical processes. Climatic features in mountainous areas, especially high mountainous regions, vary widely according to their environment. It is known that the amount of precipitation increases with increasing of elevation. Soils have been studied along a transverse section using four representative profiles between the elevations of 1139-1809 m. Soils were described in the field for geochemical properties of these four profiles were identified and samples were 
collected from each genetic horizon. Sixteen disturbed and undisturbed the samples of soil were taken to the laboratory to search for their geochemical features. Soil samples were air-dried, gently crushed, and passed through a 2-mm sieve to remove coarse fragments. Soil was used for the following analyses: Chemical determination of selected major, trace and rare earth elements was performed by Inductively Coupled Plasma Mass Spectrometer (ICP-MS) (Burt, 2011).

Table 1. Selected site characteristic of the studied profiles

\begin{tabular}{lccccccc}
\hline \multirow{2}{*}{ Pedon } & \multicolumn{2}{c}{ Coordinates } & \multirow{2}{*}{ Primary material } & \multirow{2}{*}{ Elevations (m) } & \multirow{2}{*}{ Physiography } & \multirow{2}{*}{ Slope (\%) } & \multirow{2}{*}{ Vegetation } \\
\cline { 2 - 3 } & North & South & & limestone & 1139 & Steep slope & $30-45$ \\
I & 4173828 & 360699 & limestone & 1267 & Steep slope & $30-45$ & forest \\
II & 4173563 & 335946 & limestone & 1633 & Steep slope & $30-45$ & forest \\
III & 4170197 & 354065 & limestone & 1809 & Steep slope & $>45$ & forest \\
IV & 4169545 & 352906 & &
\end{tabular}

Trace elements: A 500-mg <2-mm soil separate that has been air dried and ground to <200 mesh $(75 \mu \mathrm{m})$ was weighed into a 100-ml Teflon (PFA) sample digestion vessel. To the vessel, $9.0 \mathrm{~mL} \mathrm{HNO3} \mathrm{and} 3.0 \mathrm{~mL} \mathrm{HCl}$ were added. The vessel was inserted into a protection shield, covered and then placed into a rotor with temperature control. Following microwave digestion, the rotor and samples were cooled and the digestate was quantitatively transferred into a $50-\mathrm{ml}$ glass volumetric of high purity reverse osmosis deionized water. The samples were transferred into appropriate acid-washed polypropylene containers (Burt, 2011). While the samples of study were analyzed at the Advanced technology research \& application center Laboratories (Selcuk University in Konya, Turkey).

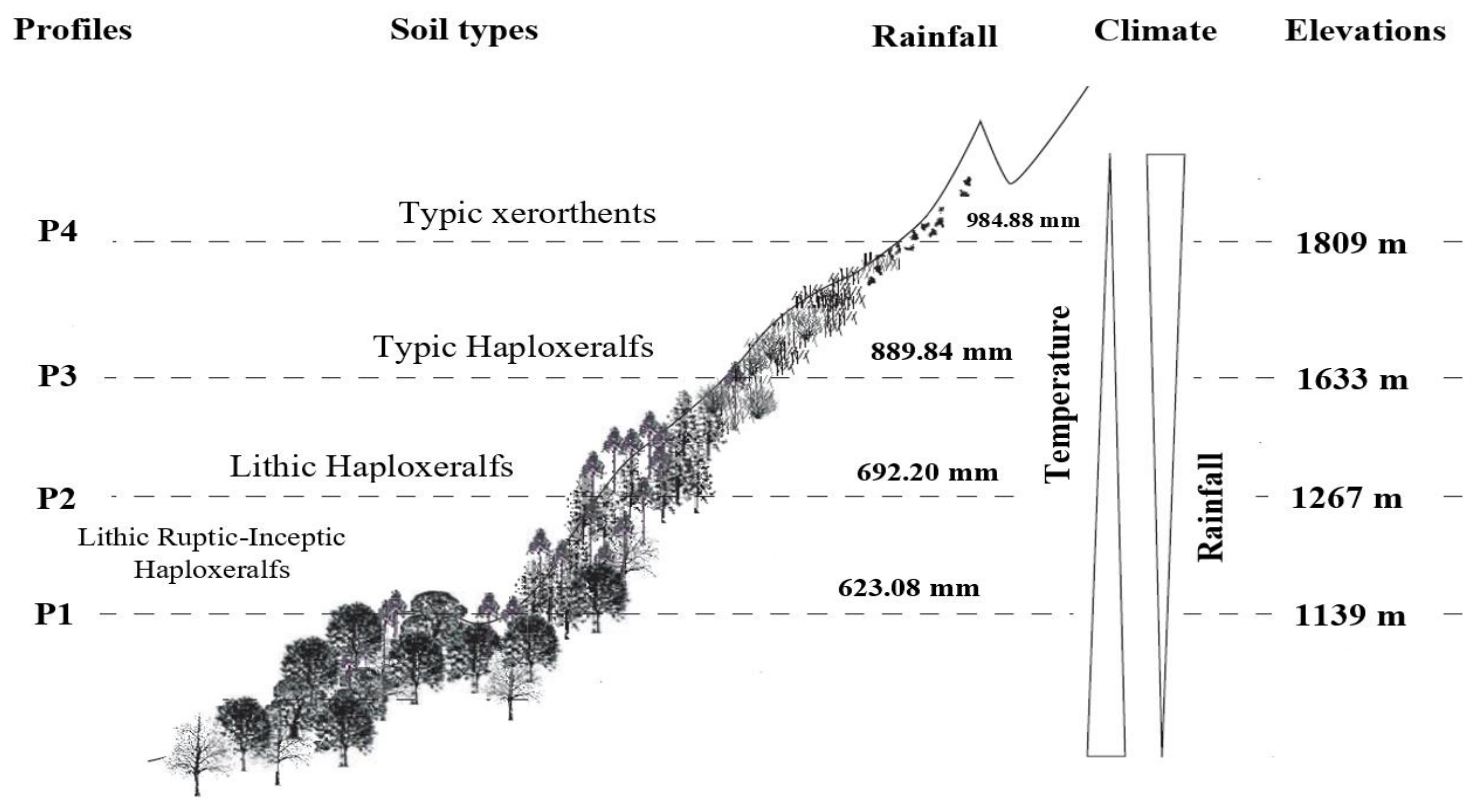

Figure 2. The amount of rainfall and the location of soil profiles during along altitudinal transect in mountain in Anamas

\section{Soil development indicators}

\section{Calculation of Chemical Weathering Indices}

Several indexes have been defined to characterize chemical weathering in soils, chemical weathering changes the chemical and mineralogical composition of a soil. Some of the mineral elements may be liberated (e.g. $\mathrm{Ca}, \mathrm{Mg}, \mathrm{K}, \mathrm{Na}$ ), forming secondary minerals, particularly clay minerals. The most commonly used chemical weathering indices are summarized in this study, such as Chemical Index of Alteration (CIA) Nesbitt and Young (1984), Chemical Index of Weathering (CIW) Harnois (1988), Plagioclase Index of Alteration (PIA) Fedo et al. (1995), Weathering Index of Parker (WIP), Parker (1970), and mineralogical index of alteration (MIA), Voicu et al. (1996), of which some of them will be discussed more in detail below.

1. $\mathrm{CIA}=(100)\left[\mathrm{Al}_{2} \mathrm{O}_{3} /\left(\mathrm{Al}_{2} \mathrm{O}_{3}+\mathrm{CaO} *+\mathrm{Na}_{2} \mathrm{O}+\mathrm{K}_{2} \mathrm{O}\right)\right]$

2. $\mathrm{CIW}=(100)\left[\mathrm{Al}_{2} \mathrm{O}_{3} /\left(\mathrm{Al}_{2} \mathrm{O}_{3}+\mathrm{CaO}^{*}+\mathrm{Na}_{2} \mathrm{O}\right)\right]$

3. $\mathrm{PIA}=(100)\left[\left(\mathrm{Al}_{2} \mathrm{O}_{3}-\mathrm{K}_{2} \mathrm{O}\right) /\left(\mathrm{Al}_{2} \mathrm{O}_{3}+\mathrm{CaO} *+\mathrm{Na}_{2} \mathrm{O}+\mathrm{K}_{2} \mathrm{O}\right)\right]$

4. $\quad$ WI P $=(100)\left[\left(2 \mathrm{Na}_{2} \mathrm{O} / 0.35\right)+(\mathrm{MgO} / 0.9)+\left(2 \mathrm{~K}_{2} \mathrm{O} / 0.25\right)+\left(\mathrm{CaO}^{*} / 0.7\right)\right]$

5. MIA $=2 *(\mathrm{CIA}-50)$

The mineralogical index of alteration (MIA) evaluates the degree of mineralogical weathering. The MIA value indicates incipient (0-20\%), weak (20-40\%), moderate (40-60\%), and intense to extreme $(60-100 \%)$ 
weathering Voicu and Bardoux (2002). Importantly, all indices are calculated with $\mathrm{CaO}^{*}$ and corrected for inputs from carbonate and apatite (McLennan et al., 1993).

\section{A-CN-K diagrams and chemical alteration (CIA)}

CIA is the most reliable weathering indices with the highest explanatory power, Therefore suggested the ternary A-CN-K $\left(\mathrm{Al}_{2} \mathrm{O}_{3}-\mathrm{CaO}^{*}+\mathrm{Na}_{2} \mathrm{O}-\mathrm{K}_{2} \mathrm{O}\right)$ system is useful for evaluating the compositions of fresh plagioclase- and potassium-feldspar- rich rocks and examining their weathering trends, weathering products and clay minerals. (Nesbitt and Young 1984; Nesbitt 1992; Fedo et al. 1995; Nesbitt et al. 1996; Buggle et al. 2011; Shao et al. 2012; Babechuk et al. 2014; Baumann et al. 2014; Regassa et al. 2014).

\section{Conduct of the rare earth elements during weathering}

Besides some geochemical ratios and $\mathrm{Ce}$ and $\mathrm{Eu}$ anomalies were used to the quantification of weathering degree of studied pedons. The REE concentrations are normalized relative to a chondritic reference standard to facilitate the comparison of REE patterns between sites. Europium is the only lanthanide that usually happens in a divalent oxidation state and whose behavior is strongly influenced by plagioclase. This results in the potential for Eu to fractionate from the other lanthanides during weathering, since plagioclase is one of the most susceptible minerals to chemical dissolution (Babechuk et al., 2014). Fractionation of Eu can be tracked using the Eu anomaly of Eu* obtained by interpolation between the normalized values of $\mathrm{Sm}$ and $\mathrm{Gd}$,

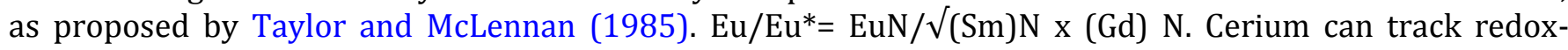
related transformations during pedogenesis in weathering profiles as a result of the potential oxidation of $\mathrm{Ce}^{3+}$ to $\mathrm{Ce}^{4+}$ (e.g., Middelburg et al., 1988; Braun et al., 1990; Mongell, 1993; Gallet et al., 1996; Murakami et al., 2001; Patino et al., 2003; Dengiz et al., 2013; Babechuk et al., 2014; Vermeire et al., 2016). Cerium anomalies are estimated by comparing the measured concentration of Ce with an expected concentration of $\mathrm{Ce}^{*}$ obtained by interpolation between the normalized values of La and Pr. Cerium anomalies can be

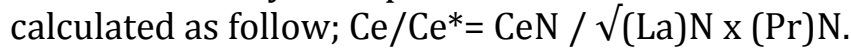

\section{Results and Discussion}

$\mathrm{SiO}_{2}$ content was lower than $53 \%$ in all profiles and ranged from $1.04 \%$ to $52.90 \%$. The content of $\mathrm{Al}_{2} \mathrm{O}_{3}$ ranged from 0.35 to $24.9 \%$. $\mathrm{Fe}_{2} \mathrm{O}_{3}$ profiles were distributed between $0.07 \%$ and $9.56 \%$. $\mathrm{MgO}$ values were changed between $0.45 \%$ and $7.13 \%$. The enrichment observed in the MgO content was very specific and it is believed that $\mathrm{MgO}$ is generally very sensitive to leaching (Arikan et al., 2007; Nordt and Driese, 2010; Regassa et al., 2014). $\mathrm{CaO}$ values were found between 0.72 and $58.90 \%$. The $\mathrm{K}_{2} \mathrm{O}$ and $\mathrm{Na}_{2} \mathrm{O}$ values were found to be $0.04-2.89 \%, 0.07-0.49 \%$, respectively. Titanium is a mineral that is resistant to decomposition and is an element used in the determination of chemical change. $\mathrm{TiO}_{2}$ contents were found to be between 0.01-0.19\%, $\mathrm{MnO} 0.02-0.32 \%$ and $\mathrm{P}_{2} \mathrm{O}_{5}$ 0.05-0.74\% (Table 2).

Table 2. Total elemental analysis in weight percentages, oxides are expressed as weight percentages for the studied soil profiles.

\begin{tabular}{|c|c|c|c|c|c|c|c|c|c|c|c|c|c|c|}
\hline $\begin{array}{l}\text { Elevations } \\
\text { (m) }\end{array}$ & Pedon & Horizon & $\begin{array}{l}\mathrm{SiO}_{2} \\
(\%)\end{array}$ & $\begin{array}{c}\mathrm{Al}_{2} \mathrm{O}_{3} \\
(\%)\end{array}$ & $\begin{array}{l}\mathrm{Fe}_{2} \mathrm{O}_{3} \\
(\%)\end{array}$ & $\begin{array}{l}\text { Mg0 } \\
(\%)\end{array}$ & $\begin{array}{l}\mathrm{CaO} \\
(\%)\end{array}$ & $\begin{array}{l}\mathrm{Na}_{2} \mathrm{O} \\
(\%)\end{array}$ & $\begin{array}{l}\mathrm{K}_{2} \mathrm{O} \\
(\%)\end{array}$ & $\begin{array}{l}\mathrm{TiO}_{2} \\
(\%)\end{array}$ & $\begin{array}{l}\mathrm{P}_{2} \mathrm{O}_{5} \\
(\%)\end{array}$ & $\begin{array}{l}\text { LOI } \\
(\%)\end{array}$ & $\begin{array}{l}\text { MnO } \\
(\%)\end{array}$ & $\begin{array}{l}\text { Sum } \\
(\%)\end{array}$ \\
\hline \multirow{4}{*}{1139} & \multirow{4}{*}{ P1 } & Oi & 19.8 & 8.61 & 3.03 & 0.84 & 4.43 & 0.09 & 1.03 & 0.43 & 0.74 & 60.1 & 0.11 & 99.23 \\
\hline & & A & 44.8 & 21.0 & 8.13 & 1.38 & 1.51 & 0.15 & 2.65 & 1.16 & 0.52 & 18.2 & 0.17 & 99.68 \\
\hline & & $\mathrm{Bt}$ & 46.8 & 24.9 & 9.56 & 1.33 & 1.24 & 0.09 & 2.49 & 1.17 & 0.23 & 11.7 & 0.15 & 99.67 \\
\hline & & CR & 1.04 & 0.35 & 0.07 & 0.45 & 58.90 & 0.17 & 0.04 & 0.01 & 0.05 & 38.7 & 0.10 & 99.79 \\
\hline \multirow{4}{*}{1267} & \multirow{4}{*}{ P2 } & Oi & 31.0 & 13.0 & 5.26 & 1.82 & 2.67 & 0.19 & 1.61 & 0.63 & 0.24 & 42.8 & 0.24 & 99.48 \\
\hline & & A & 37.7 & 16.7 & 7.10 & 3.25 & 4.88 & 0.21 & 2.04 & 0.84 & 0.22 & 26.5 & 0.32 & 99.77 \\
\hline & & Btk & 29.7 & 15.3 & 5.47 & 5.05 & 21.60 & 0.16 & 1.66 & 0.70 & 0.14 & 20.0 & 0.16 & 99.96 \\
\hline & & $\mathrm{C}$ & 24.0 & 10.6 & 3.50 & 7.13 & 29.20 & 0.11 & 1.04 & 0.44 & 0.08 & 23.5 & 0.21 & 99.84 \\
\hline \multirow{5}{*}{1633} & \multirow{5}{*}{ P3 } & Oi & 9.13 & 4.05 & 1.19 & 0.45 & 2.61 & 0.07 & 0.57 & 0.17 & 0.12 & 81.3 & 0.02 & 99.70 \\
\hline & & A & 38.8 & 17.2 & 6.04 & 1.24 & 2.14 & 0.20 & 2.62 & 0.85 & 0.17 & 30.3 & 0.14 & 99.71 \\
\hline & & Bhw & 43.6 & 20.7 & 7.57 & 1.40 & 5.34 & 0.21 & 3.31 & 0.99 & 0.20 & 16.4 & 0.14 & 99.87 \\
\hline & & $\mathrm{Ck}$ & 31.4 & 16.5 & 5.09 & 1.13 & 23.20 & 0.15 & 2.60 & 0.70 & 0.20 & 18.8 & 0.06 & 99.85 \\
\hline & & $\mathrm{Cr}$ & 48.4 & 20.5 & 5.60 & 1.38 & 7.49 & 0.21 & 3.44 & 1.00 & 0.13 & 11.7 & 0.04 & 99.91 \\
\hline \multirow{4}{*}{1809} & \multirow{4}{*}{ P4 } & A1 & 39.9 & 15.7 & 5.80 & 1.42 & 2.90 & 0.40 & 2.58 & 0.87 & 0.16 & 30.5 & 0.13 & 100.37 \\
\hline & & A2 & 44.1 & 17.6 & 6.70 & 1.47 & 2.44 & 0.43 & 2.89 & 1.02 & 0.14 & 22.9 & 0.12 & 99.82 \\
\hline & & C1 & 52.0 & 21.1 & 8.25 & 1.59 & 0.94 & 0.49 & 3.69 & 1.19 & 0.15 & 10.4 & 0.15 & 99.96 \\
\hline & & $\mathrm{Cr}$ & 52.9 & 21.1 & 8.27 & 1.53 & 0.72 & 0.48 & 3.68 & 1.15 & 0.15 & 9.78 & 0.15 & 99.93 \\
\hline
\end{tabular}

In Figure 3, the depth is plotted against the element content in weight percentages. While the chemical elements show similar tendencies in the 1,2 and 3 profiles, the trends in the 4 profiles are different. Generally, in the fourth profile: reduced the content of $\mathrm{CaO}$ and $\mathrm{P}_{2} \mathrm{O}_{5}$ and increased $\mathrm{SiO}_{3}, \mathrm{Al}_{2} \mathrm{O}_{3}, \mathrm{Fe}_{2} \mathrm{O}_{3}, \mathrm{TiO}_{2}$, $\mathrm{MgO}, \mathrm{Na}_{2} \mathrm{O}, \mathrm{MnO}$ and $\mathrm{K}_{2} \mathrm{O}$ were shown at decreased depth. $\mathrm{Fe}, \mathrm{Al}, \mathrm{Si}$ the total content increases as the soil depth decreases due to the washing of carbonates. The $\mathrm{P}_{2} \mathrm{O}_{5}$ line in the first profile also deviates from the general trend to the top. 
PI
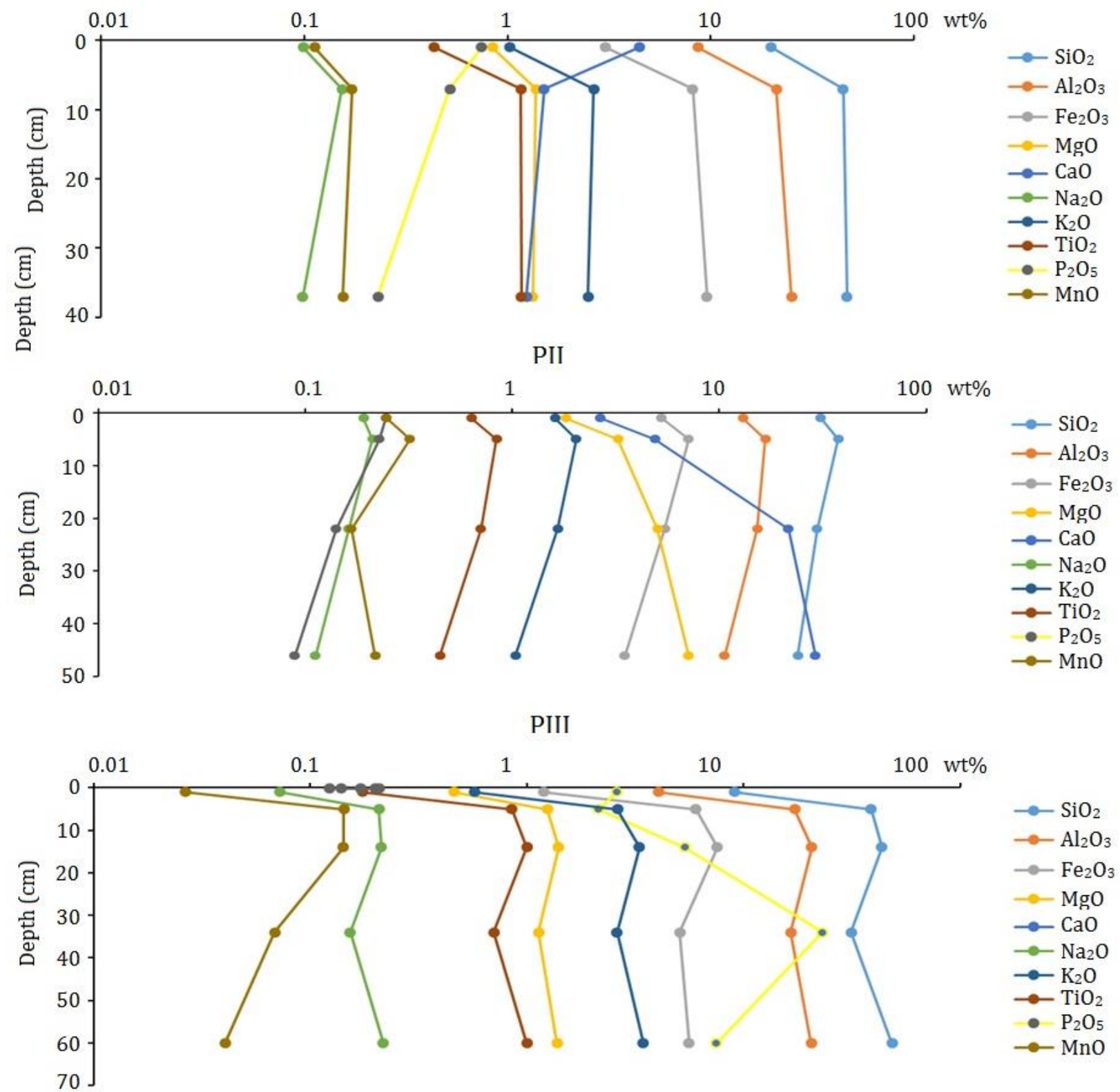

PIV

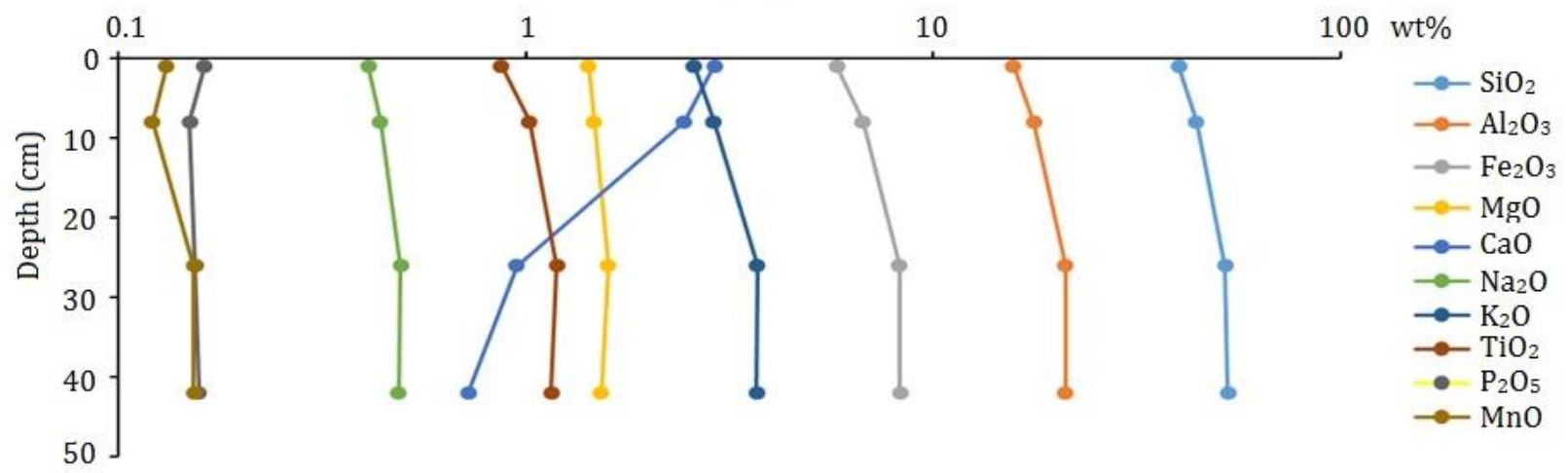

Figure 3. Total elements contents (in wt\%) with depths for the studied soil profiles on a logarithmic scale.

The increase in $\mathrm{P}_{2} \mathrm{O}_{5}$ content may be due to the presence of both micro and macro organisms, causing retention of the element in their tissue. An increase in the amount of free sesquioxides resulting from the weathering of primary minerals also increase the phosphorous fixation capabilities of the weathered material. The effects of geochemical elements and the weathering indices, on the formation of the soils using the total element results, will be explained in the following sections. 


\section{Chemical weathering indices}

The role of chemical weathering indices is mainly; to determine the amount of yield of the mobile components during weathering, assess soil fertility, to provide better kinetic element mobility in the context of weathering and predict the source of soil nutrients as well as changes in metal nutrients (Harnois 1988; Şenol et al., 2018). The values were gives of chemical weathering indicators for CIA\%, CIW\%, PIA\%, MIA\% and WIP. A change is observed for all soil values (89.19-79.00, 98.72-92.11, 79.53-64.04, 78.37-58.00, 41.38$12.21 \%)$ respectively. From the figures $(4,5,6)$, it was revealed that the depth of the soil profiles $(1,2$ and 3$)$ increases with increasing the weathering indexes of the subsurface horizons. In addition, the most soluble elements such as $\mathrm{MgO}, \mathrm{CaO}, \mathrm{Na}_{2} \mathrm{O}$ and $\mathrm{K}_{2} \mathrm{O}$ increase the $\mathrm{CIA}, \mathrm{CIW}$ and PIA due to the fact that they move towards the depth. Due to the low content of $\mathrm{Al}_{2} \mathrm{O}_{3}$ as a result of clay migration in the soil, the values of the weathering indicators on the surface of the horizons at profiles (1,2 and 3) were lower. It is important to emphasize that the removal of $\mathrm{K}$ from potassium feldspar is less than the rates of $\mathrm{Na}$ and $\mathrm{Ca}$ removal from plagioclase. However, potassium Feldspars is more sensitive to weathering. Accordingly, CIW is equivalent to that of CIA without potassium. If it is not aluminum associated with potassium feldspar, the CIW value will therefore be high and will cause errors in rocks the rich Feldspar. In general, in Figure 7, it was observed that the low WIP value in all soil profiles of surface horizons, and the low WIP value indicate a decrease in the moving cations. At the high altitudes of the fourth soil profiles, the highest WIP was observed and decreased at low altitudes due to the increase in $\mathrm{K}, \mathrm{Na}, \mathrm{Ca}, \mathrm{Mg}$ cations. Figure 8 shows the index of mineralogical alteration evaluation to assess the degree of weathering. The amount of MIA increases with increasing depth at profiles (1,2 and 3) and is considered the most developed soils at medium and low altitudes. The rate of chemical weathering of CIA, CIW, PIA and MIA indicators for all studied soil profiles (as shown in the Figure 9) decreases with the increase in elevation. This is due to the fact that basic cations (K, $\mathrm{Na}, \mathrm{Ca}$ and $\mathrm{Mg}$ ) are dissolved in water and descaled by leaching processes, cations accumulate at low altitudes and contribute to the formation of secondary minerals. In contrast, WIP value is increased at higher altitudes due to increased leaching and precipitation at high altitudes causing decrease in movement of cations. Although less developed soils are found at the steepest slopes of the P4 with a height of $1809 \mathrm{~m}$, they contain less mobile elements, due to the leaching of products weathering that cause decomposition conditions and their transfer to low altitudes, which is more pronounced in the soil developed for profile at elevation $1139 \mathrm{~m}$.

\section{CIA. \%}

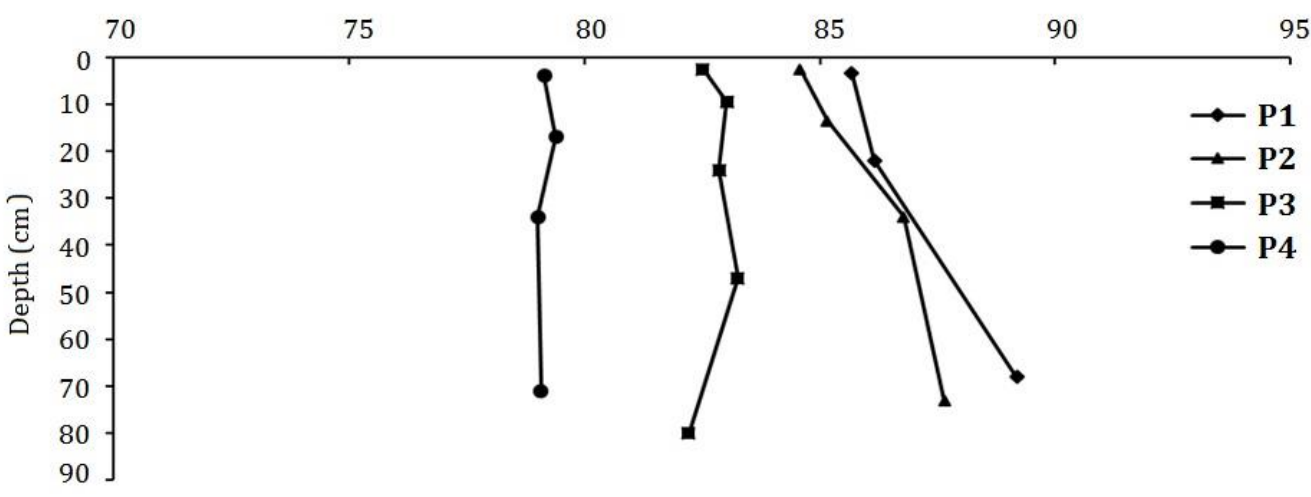

Figure 4. CIA \% with depths for the studied soil profiles.

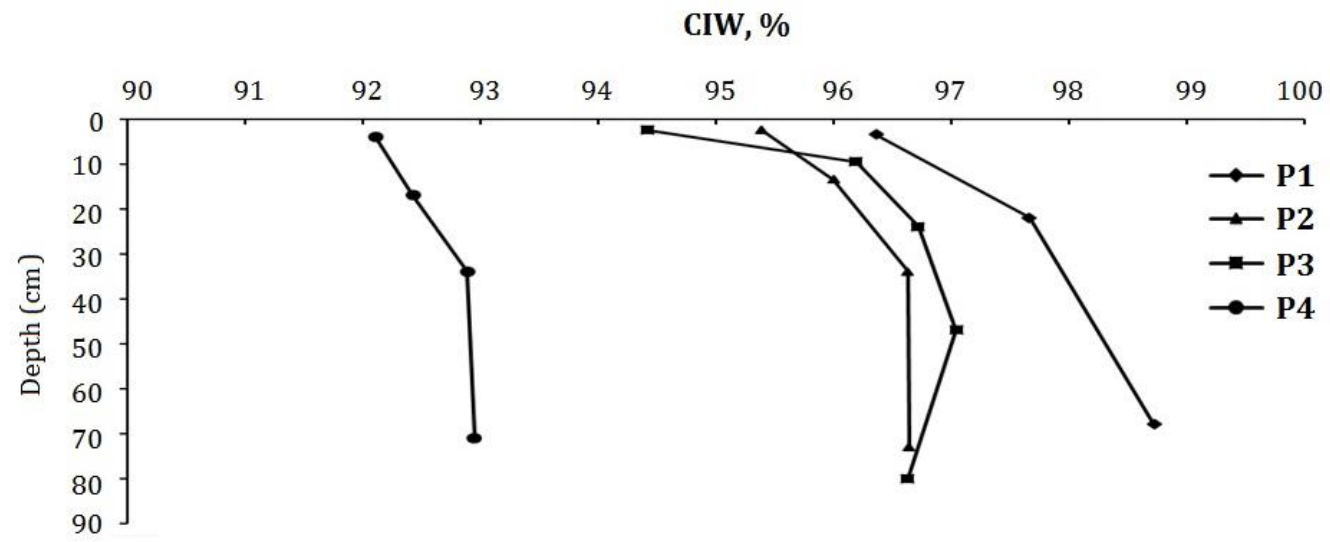

Figure 5. CIW \% with depths for the studied soil profiles. 


\section{PIA, \%}

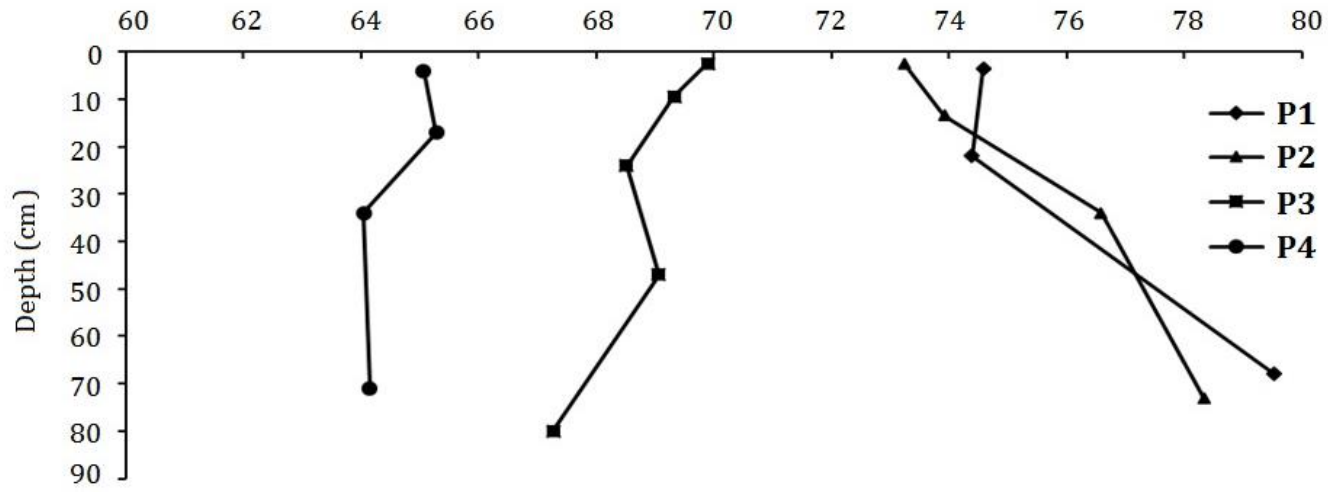

Figure 6. PIA \% with depths for the studied soil profiles.

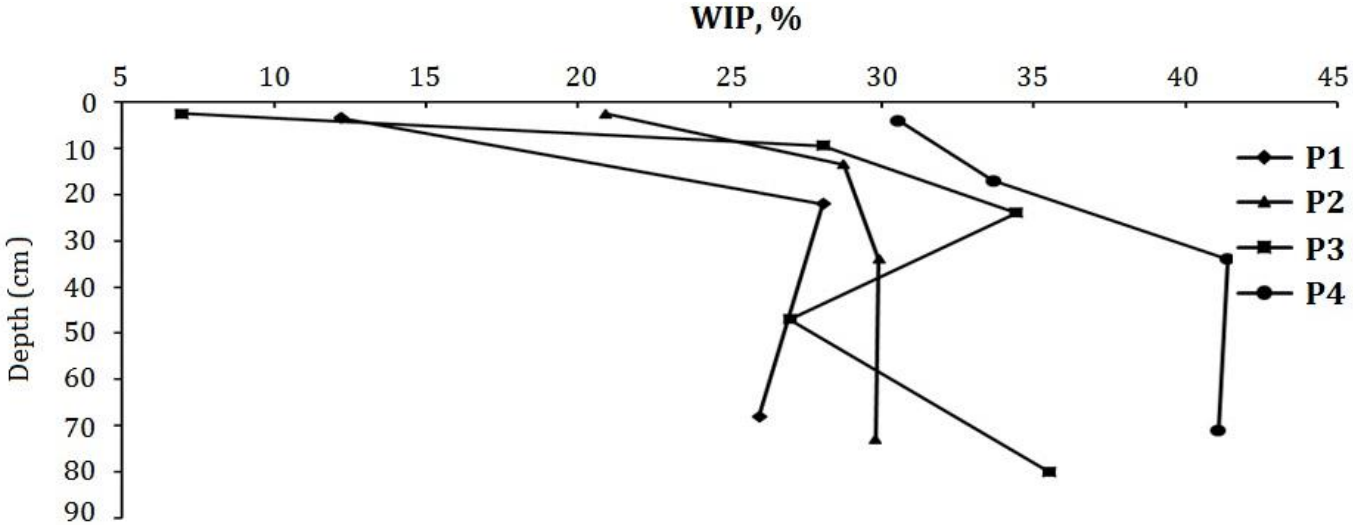

Figure 7. PIA \% with depths for the studied soil profiles.

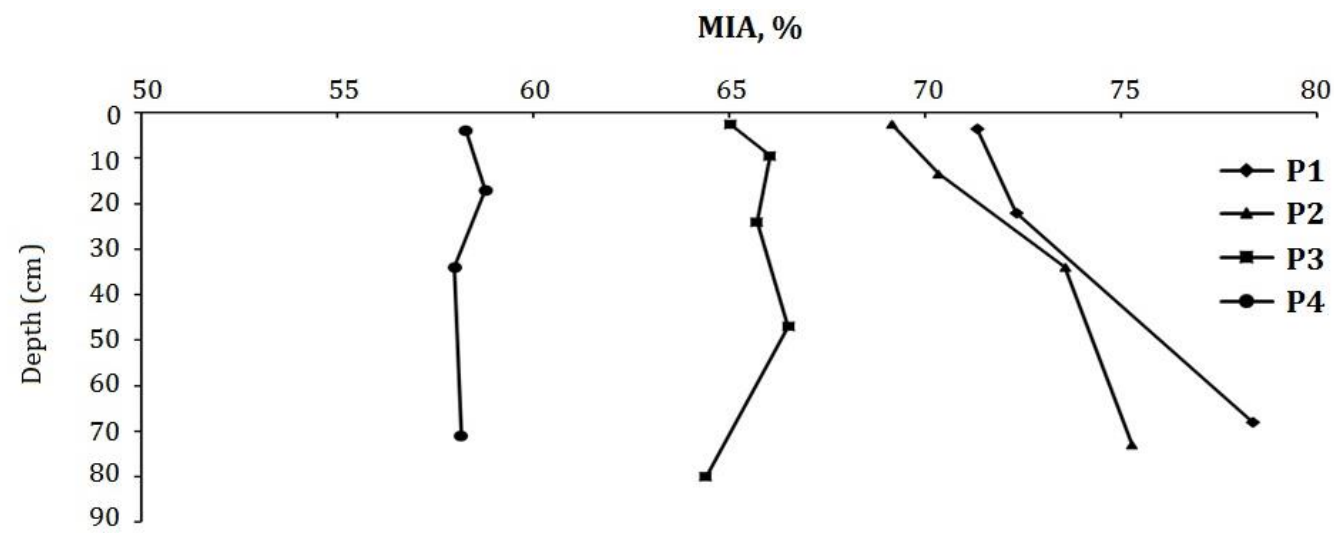

Figure 8. MIA \% with depths for the studied soil profiles.

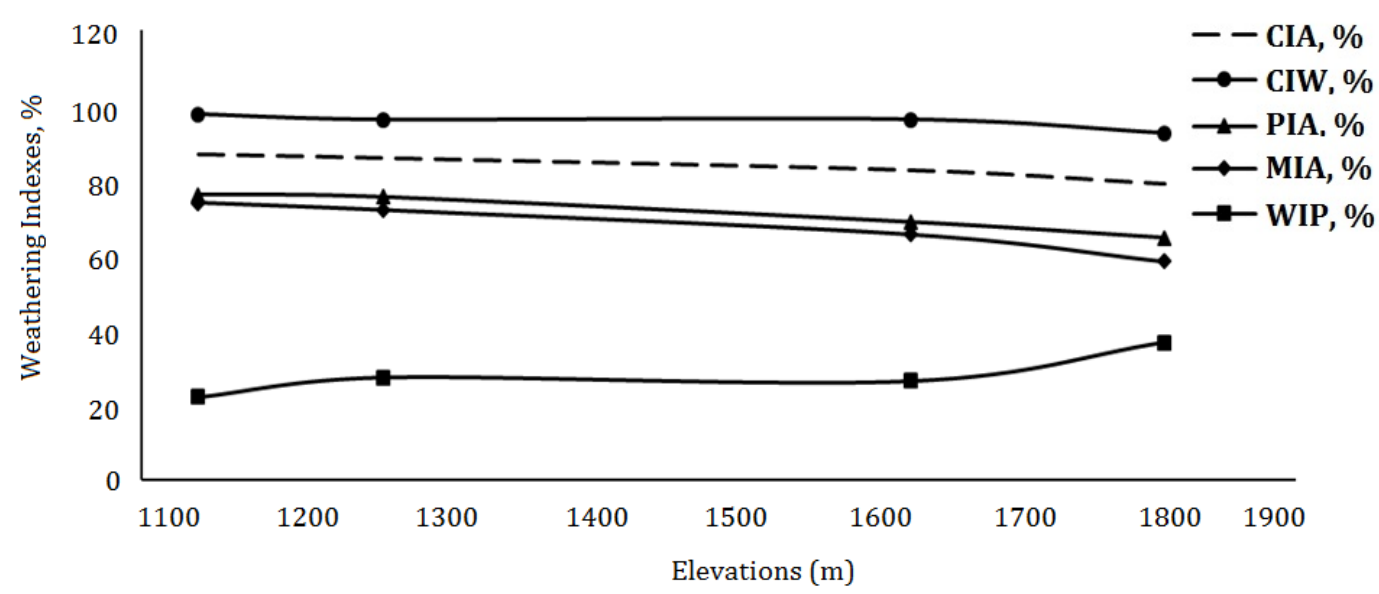

Figure 9. Weathering Indexes $\%$ with elevations for the studied soil profiles. 


\section{A-CN-K diagrams and chemical alteration (CIA)}

Generally, the CIA is considered as a measure of the extent of the conversion of feldspar to clay (Nesbitt and Young, 1982; Nesbitt and Young, 1989; Fedo et al., 1995; Nesbitt et al., 1996; Yang et al., 2004; Buggle et al., 2011; Che et al., 2012; Shao et al., 2012; Babechuk et al., 2014; Baumann et al., 2014; Regassa et al., 2014).

Degradation of feldspar and concomitant formation of clay minerals are the dominant processes during chemical weathering of the soil. The A-CN-K $\left(\mathrm{Al}_{2} \mathrm{O}_{3}-\mathrm{Ca} \mathrm{O}+\mathrm{Na}_{2} \mathrm{O}-\mathrm{K}_{2} \mathrm{O}\right)$ diagram was proposed to intuitively reflect the trends and the degree of silicate weathering and to evaluate the clay minerals (Nesbitt and Young, 1989; Fedo et al., 1995; Nesbitt et al., 1996; Von Eynatten et al., 2003; Yang et al., 2004; Li and Yang, 2010; Buggle et al., 2011). On the A-CN-K diagram, the main trend of silicate weathering in leaching of $\mathrm{CaO}$ and $\mathrm{Na}_{2} \mathrm{O}$ and then $\mathrm{K}_{2} \mathrm{O}$, and relative enrichment of $\mathrm{Al}_{2} \mathrm{O}_{3}$. Note that most of the investigated soils indicate weathering trends in parallel with the $\mathrm{A}-\mathrm{K}$ line. Most likely reflecting strong removal of $\mathrm{K}$-bearing minerals from the parent rocks. The most weathered soils plot at the top of the triangle located the $A$ apex reflecting high concentrations of Al-bearing minerals (Figure 10). The CIA values are directly represented on the A-CN edge of the A-CN-K triangle Figure 10 as the elements involving this edge are the same as needed for the calculation of CIA. High CIA values reflected the removal of labile cations relative to stable residual constituents during weathering, and low CIA values indicate the near absence of chemical alteration (Nesbitt and Young, 1982).

In contrast, the soils at elevation $1139 \mathrm{~m}$ are parallel to the A-K line and approach the A apex more than the other soil elevations, most likely reflecting strong removal of K-bearing minerals from the parent rocks (Figure 10). This was due to the degree of weathering that they are higher than other heights, so the soil is considered the most developed. Despite the different weathering intensities registered in studied soil profiles, most of the investigated studied soils seem to be weathered from similar parent rocks. However, exhibited different weathering directions by deviating from the main trend in the A-CN-K diagram Figure 10, suggesting that composition of weathered soils more easily influenced by quantity of precipitation and the climate differences by the difference in altitudes.

\section{Conduct of the rare earth elements during weathering:}

It is known that the soil's REE concentration is influenced by sequential soil processes during pedogenesis (REE), REE is affected by a series of processes leading to internal degradation, such as solubility, oxidation, reduction, precipitation Babechuk et al. (2014). Table 3 gives the values in the distribution of rare elements except for the fourth profile, there is no regular trend between the horizons, and the content of the elements increased with decreased depth, because of the increase in the amount of precipitation and thus increasing the leaching process in the fourth profile.

Table 3. The rare earth elements analysis (REE) are expressed as $\mu \mathrm{g} \cdot \mathrm{kg}^{-1}$ for the studied soil profiles.

\begin{tabular}{|c|c|c|c|c|c|c|c|c|c|c|c|c|c|c|c|c|}
\hline $\begin{array}{l}\text { Elevations } \\
\text { (m) }\end{array}$ & Pedon & Horizon & La & $\mathrm{Ce}$ & Pr & Nd & Sm & Eu & Gd & Tb & Dy & Но & Er & Tm & $\mathbf{Y b}$ & Lu \\
\hline \multirow{4}{*}{1139} & \multirow{4}{*}{ P1 } & $\mathrm{Oi}$ & 36 & 73 & 7.7 & 28 & 5.0 & 1.14 & 5.0 & 0.63 & 3.5 & 0.66 & 2.0 & 0.27 & 1.8 & 0.26 \\
\hline & & A & 75 & 142 & 15.9 & 58 & 10.7 & 2.4 & 10.5 & 1.36 & 7.5 & 1.42 & 4.2 & 0.57 & 3.8 & 0.56 \\
\hline & & $\mathrm{Bt}$ & 82 & 144 & 16.9 & 61 & 10.7 & 2.5 & 10.5 & 1.31 & 7.2 & 1.36 & 4.0 & 0.55 & 3.6 & 0.53 \\
\hline & & CR & 0.36 & 0.67 & 0.15 & 0.56 & 0.1 & 0.0 & 0.0 & 0.0 & 0.07 & 0.01 & 0.0 & 0.0 & 0.02 & 0.00 \\
\hline \multirow{4}{*}{1267} & \multirow{4}{*}{ P2 } & $\mathrm{Oi}$ & 31 & 64 & 7.4 & 29 & 5.7 & 1.2 & 5.8 & 0.81 & 4.5 & 0.86 & 2.5 & 0.34 & 2.2 & 0.33 \\
\hline & & A & 35 & 72 & 8.4 & 32 & 6.5 & 1.39 & 6.7 & 0.92 & 5.2 & 0.98 & 2.9 & 0.4 & 2.7 & 0.38 \\
\hline & & Btk & 23 & 48 & 5.4 & 21 & 3.9 & 0.82 & 3.9 & 0.55 & 3.2 & 2.65 & 1.9 & 0.28 & 1.8 & 0.26 \\
\hline & & $\mathrm{C}$ & 15.2 & 34 & 3.7 & 13.8 & 2.7 & 0.54 & 2.7 & 0.39 & 2.3 & 0.45 & 1.4 & 0.19 & 1.3 & 0.20 \\
\hline \multirow{5}{*}{1633} & \multirow{5}{*}{ P3 } & Oi & 13.8 & 28 & 3.3 & 11.9 & 2.3 & 0.52 & 2.3 & 0.32 & 1.8 & 0.35 & 0.98 & 0.16 & 0.98 & 0.16 \\
\hline & & A & 39 & 81 & 9.2 & 35 & 6.8 & 1.43 & 6.8 & 0.92 & 5.06 & 0.97 & 2.9 & 0.42 & 2.66 & 0.41 \\
\hline & & Bhw & 40 & 79 & 9.4 & 35 & 6.8 & 1.44 & 6.7 & 0.91 & 5.2 & 1.0 & 3.0 & 0.4 & 2.8 & 0.42 \\
\hline & & $\mathrm{Ck}$ & 26 & 51 & 5.9 & 21 & 3.9 & 0.79 & 3.7 & 0.5 & 2.9 & 0.56 & 1.8 & 0.25 & 1.74 & 0.26 \\
\hline & & $\mathrm{Cr}$ & 33 & 68 & 7.9 & 30 & 5.5 & 1.09 & 5.0 & 0.68 & 3.8 & 0.71 & 2.3 & 0.32 & 2.2 & 0.34 \\
\hline \multirow{4}{*}{1809} & \multirow{4}{*}{ P4 } & A1 & 35 & 70 & 8.3 & 32 & 6.2 & 1.32 & 6.2 & 0.83 & 4.8 & 0.9 & 2.6 & 0.37 & 2.5 & 0.37 \\
\hline & & A2 & 38 & 78 & 9.2 & 35 & 6.9 & 1.44 & 6.8 & 0.95 & 5.3 & 1.02 & 2.9 & 0.42 & 2.8 & 0.41 \\
\hline & & C1 & 41 & 84 & 9.9 & 38 & 7.4 & 1.5 & 7.3 & 1.03 & 5.7 & 1.09 & 3.2 & 0.45 & 3.0 & 0.44 \\
\hline & & $\mathrm{Cr}$ & 40 & 81 & 9.7 & 37 & 7.2 & 1.5 & 7.0 & 0.97 & 5.6 & 1.11 & 3.3 & 0.47 & 3.0 & 0.47 \\
\hline
\end{tabular}

Table 4 gives the values in the indicators were calculated according to their geochemical percentages to determine weathering and soil enrichment rates. According to this; $\mathrm{Yb}(\mathrm{N}), \mathrm{La}(\mathrm{N})$ and $\mathrm{Lu}(\mathrm{N})$ values representing the LREE / HREE values in the soil were examined, La /Lu and La/Yb were found to be positive and strong, all of them were subjected to leaching as a result of all soil values. The low rate of $1809 \mathrm{~m}$ of $\mathrm{La} / \mathrm{Lu}$ in $\mathrm{P} 4$ indicates a relatively low weathering condition and a low amount of clay found in the soil. On the other hand, the distribution of the $\mathrm{Sm}(\mathrm{N})$ and $\mathrm{La}(\mathrm{N})$ ratios is very close to the MREE, the middle rare enrichment element. The low negative $\mathrm{Sm} / \mathrm{Nd}$ ratio for the values of all the soil profiles studied was found to 
be related to the intensity of the increased weathering in relation to the LREE enrichment. The ratios obtained using REE trace elements in (Table 4) showed that the clay movement in P1 was denser and thus the weathering was more developed than the other studied soil profiles. In addition, for $\mathrm{La} / \mathrm{Sm}, \mathrm{La} / \mathrm{Lu}$ and $\mathrm{La} / \mathrm{Yb}$ ratios for $\mathrm{P} 1$, it is due to the increased elevation of $1139 \mathrm{~m}$ without any other soil profiles studied.

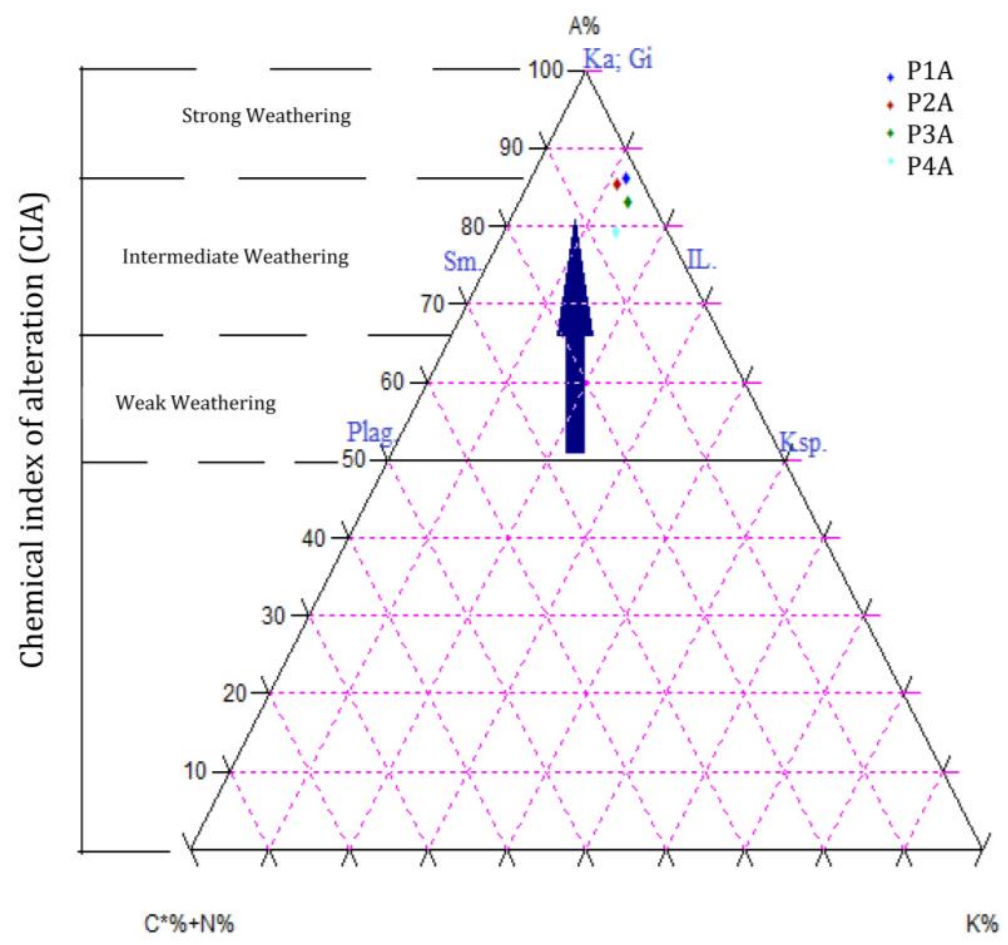

Figure 10. A-CN-K diagrams (Nesbitt and Young, 1989) with indication of the weathering index CIA for studied soil profiles only for horizon A. Arrow indicates the general weathering trend and the minerals plagioclase (Plag.), Kfeldspar (Ksp.), Illite (IL.), Smectite (Sm.), Kaolinite (Ka.), and gibbsite (Gi.) is give for orientation.

Ho is a leachable element with weathering. Therefore, Er/Ho ratios tend to decrease by increasing weathering. In Table 4, P4 means that the highest Er/Ho ratio for height $1809 \mathrm{~m}$, was the lowest density of weathering at this height. However, the lowest value of Er/Ho ratio at the elevation of $1139 \mathrm{~m}$ indicates that the density of weathering has increased.

It is clear that all values in the samples of the soil profiles examined have Eu negative. Eu/Eu* values are between $0.61-0.72 \%$ as shown in Table 4 . More importantly, the difference in the $\mathrm{Eu} / \mathrm{Eu}^{*}$ value is inversely proportional to the increased weathering. Similar reports of a decrease in the negative values of $\mathrm{Eu} / \mathrm{Eu}^{*}$ as a function of intensity of weathering are presented (Condi et al., 1995; Huang and Gong, 2001; Ma et al., 2011; Babechuk et al., 2014).

Cerium can monitor cases of oxidation due to the potential oxidation bond between $\mathrm{Ce}^{+3}$ and $\mathrm{Ce}^{+4}$ during pedogenesis processes in populations of soil profiles studied. Cerium (cerium) was estimated by using the formulas of $\mathrm{Ce}$, La and Pr. In Table 4, $\mathrm{Ce} / \mathrm{Ce}^{*}$ values are weak positive and negative. These oxidation values show that in the weathering of all studied soil profiles, Ce will decompose on a smaller scale.

\section{Conclusion}

The aim of this research was characterizing the geochemical characteristics of soils as a function of climate to evaluate the soil formation and weathering rates in Climosequence depending on the elevation by using geochemical data. The rate of chemical weathering of CIA, CIW, PIA and MIA indicators decreased with the increase in elevation. This was because basic cations $(\mathrm{K}, \mathrm{Na}, \mathrm{Ca}$ and $\mathrm{Mg}$ ) were dissolved in water and descaled by leaching processes, and cations accumulated at low altitudes and contributed to the formation of secondary minerals. In contrast, WIP value was increased at higher altitudes due to increased leaching and precipitation at high altitudes causing decrease in movement of cations. Although less developed soils were found at the steepest slopes of the P4 with a height of $1809 \mathrm{~m}$, they contained less mobile elements, due to the leaching of products weathering that cause decomposition conditions and their transfer to low altitudes, which is more pronounced in the soil developed for the first profile at elevation $1139 \mathrm{~m}$.

Despite the different weathering intensities and anomalies registered in studied soil profiles, most of the investigated studied soils seemed to be weathered from similar parent rocks. However, it exhibited different weathering directions by deviating from the main trend in the A-CN-K diagram suggesting that the formation 
of weathered soils more easily influenced by quantity of precipitation, degree of gradient and difference elevations. Therefore, it was concluded that the main factors determining soil formation are climate and elevations, both of which determine the leaching regime and weathering rates.

\section{Acknowledgments}

This study is a part of Ph.D Thesis titled "Pedogenic evaluation and chemical weathering rates of soils developed along an altitudinal transect" conducted by Omar ALSALAM and it was taken from a research project supported by Selçuk University (S.U.) BAP Office (Coordinating Office of Scientific Research Projects, Project No: 18201141). The authors would like to thank "the S.U.-BAP staffs".

\section{References}

Arikan, F., Ulusay, R., Aydin, N., 2007. Characterization of weathered acidic volcanic rocks and a weathering classification based on a rating system. Bulletin of Engineering Geology and the Environment 66: 415-430.

Babechuk, M.G., Widdowson, M., Kamber, B.S., 2014. Quantifying chemical weathering intensity and trace element release from two contrasting basalt profiles, Deccan Traps, India. Chemical Geology 363: 56-75.

Barboso, W.R., Romero, R.E., de Souza Júnior, M.S., Cooper, M., Sartor, L.R., de Moya Partiti, C.S., de Oliveira Jorge, O., Cohen, R., de Jesus, S.L., Ferreira, T.O., 2015. Effects of slope orientation on pedogenesis of altimontane soils from the Brazilian semi-arid region (Baturité massif, Ceará). Environmental Earth Sciences 73(7): 3731-3743.

Baumann, F., Schmidt, K., Dörfer, C., He, S.J., Scholten, T., Kühn, P., 2014. Pedogenesis, permafrost, substrate and topography: Plot and landscape scale interrelations of weathering processes on the central-eastern Tibetan Plateau. Geoderma 226-227: 300-316.

Braun, J.J., Viers, J., Dupré, B., Polve, M., Ndam, J., Muller, J.P., 1998. Solid/Liquid REE fractionation in the lateritic system of Goyoum, East Cameroon: The implication for the present dynamics of the soil covers of the humid tropical regions. Acta 62(2): 273-299.

Buggle, B., Glaser, B., Hambach, U., Gerasimenko, N., Marković, S., 2011. An evaluation of geochemical weathering indices in loess-paleosol studies. Quaternary International 240(1-2): 12-21.

Burt, R., 2011. Soil Survey laboratory information Manual. $2^{\text {nd }}$ Edition. United States Department of Agriculture, Natural Resources Conservation Service. 305p.

Che, V.B., Fontijn, K., Ernst, G.G.J., Kervyn, M., Elburg, M., Van Ranst, E., Suh, C.E., 2012. Evaluating the degree of weathering in landslide-prone soils in the humid tropics: The case of Limbe, SW Cameroon. Geoderma 170: 378 389.

Condie, K.C. Dengate, J., Cullers, R.L., 1995. Behavior of rare earth elements in a paleoweathering profile on granodiorite in the Front Range, Colorado, USA. Geochimica et Cosmochimica Acta 59(2): 279-294.

Dengiz, O., Saglam, M., Ozaytekin, H.H., Baskan, O., 2013. Weathering rates and some physico-chemical characteristics of soils developed on a calcic toposequences. Carpathian Journal of Earth and Environmental Sciences 8(2): 13-24.

Egli, M., Mirabella, A., Sartori, G., Fitze, P., 2003. Weathering rates as a function of climate: results from a climosequence of the Val Genova (Trentino, Italian Alps). Geoderma 111(1-2): 99-121.

Egli, M., Mirabella, A. , Sartori, G. , Zanelli, R. , Bischof, S., 2006. Effect of north and south exposure on weathering rates and clay mineral formation in Alpine soils. Catena 67(3): 155 -174.

Egli, M, Mirabella, A., Sartori, G., 2008. The role of climate and vegetation in weathering and clay mineral formation in late Quaternary soils of the Swiss and Italian Alps. Geomorphology 102(3-4): 307-324.

Egli, M., Sartori, G., Mirabella, A., Favilli, F., Giaccai, D., Delbos, E., 2009. Effect of north and south exposure on organic matter in high Alpine soils. Geoderma 149(1-2):124-136.

Fedo, C.M., Nesbitt, H.W., Young, G.M., 1995. Unraveling the effects of potassium metasomatism in sedimentary rocks and paleosols, with implications for paleoweathering conditions and provenance. Geology 23(10): 921-924.

Gallet, S., Jahn, B.M., Torii, M., 1996. Geochemical characterization of the Luochuan loess-paleosol sequence, China, and paleoclimatic implications. Chemical Geology 133(1-4): 67-88.

Harnois, L., 1988. The CIW index: A new chemical index of weathering. Sedimentary Geology 55(3-4): 319-322.

Huang, C.M., Gong, Z.T., 2001. Geochemical implication of rare earth elements in process of soil development. Journal Rare Earths 19(1): 57-62.

Le Blond, J.S. , Cuadros, J., Molla, Y.B. , Berhanu, T., Umer, M., Baxter, P.J., Davey, G., 2015. Weathering of the Ethiopian volcanic province: A new weathering index to characterize and compare soils. American Mineralogist 100(1112): 2518-2232.

Li, C., Yang, S.Y., 2010. Is chemical index of alteration a reliable proxy for chemical weathering in global drainage basins? American Journal of Science 310 (2): 111-127.

Lybrand, R., Rasmussen, C., Jardine, A., Troch, P., Chorover, J., 2011. The effects of climate and landscape position on chemical denudation and mineral transformation in the Santa Catalina mountain critical zone observatory. Applied Geochemistry 26:S80-S84.

Ma, L., Jin, L., Brantley, S. L., .2011. How mineralogy and slope aspect affect REE release and fractionation during shale weathering in the Susquehanna/Shale Hills Critical Zone Observatory. Chemical Geology 290(1-2): 31-49.

McLennan, S.M., 1993. Weathering and global denudation. The Journal of Geology 101(2): 295-303.

Middelburg, J.J., van der Weijden, C.H., Woittiez, J.R.W., 1988. Chemical processes affecting the mobility of major, minor 
and trace elements during weathering of granitic rocks. Chemical Geology 68(3-4): 253-273.

Moazallahi, M., Farpoor, M.H., 2012. Soil genesis and clay mineralogy along the xeric aridic climotoposequence in South Central Iran. Journal of Agricultural Science and Technology 14(3): 683-696.

Mongelli, G., 1993. REE and other trace elements in a granitic weathering profile from "Serre", southern Italy. Chemical Geology 103(1-4): 17-25.

Murakami, T., Utsunomiya, S., Imazu, Y., Prasad, N., 2001. Direct evidence of late Archean to early Proterozoic anoxic atmosphere from a product of 2.5 Ga old weathering. Earth and Planetary Science Letters 184(2): 523-528.

Nesbitt, H.W., Young, G.M., 1982. Early Proterozoic climates and plate motions inferred from major element chemistry of lutites. Nature 279: 715-717.

Nesbitt, H.W., Young, G.M., 1984. Prediction of some weathering trends of plutonic and volcanic rocks based on thermodynamic and kinetic considerations. Geochimica et Cosmochimica Acta 48(7): 1523-1534.

Nesbitt, H.W., Young, G.M., 1989. Formation and diagenesis of weathering profiles. Journal of Geology 97(2): 129-147.

Nesbitt, H.W., 1992. Diagenesis and metasomatism of weathering profiles, with emphasis on Precambrian paleosols. Developments in Earth Surface Processes 2:127-152.

Nesbitt, H.W., Young, G.M., McLennan, S., Keays, R., 1996. Effects of chemical weathering and sorting on the petrogenesis of siliciclastic sediments, with implications for provenance studies. Journal Geology 104(5): 525-542.

Nordt, L.C., Driese, S.D., 2010. New weathering index improves paleorainfall estimates from Vertisols. Geology 38(5): 407-410.

Osat, M., Heidari, A., Eghbal, M.K., Mahmoodi, S., 2016. Impacts of topographic attributes on Soil Taxonomic Classes and weathering indices in a hilly landscape in Northern Iran. Geoderma 281: 90-101.

Parker, A., 1970. An index of weathering for silicate rocks. Geological Magazine 107(6): 501-504.

Patino, L.C., Velbel, M.A., Price, J.R., Wade, J.A., 2003. Trace element mobility during spheroidal weathering of basalts and andesites in Hawaii and Guatemala. Chemical Geology 202(3-4): 343-364.

Pettapiece, W.W., Pawluc, S., 1972. Clay mineralogy of soils developed partially from volcanic ash. Soil Science Society of America journal 36(3): 515-519.

Price, J.R., Velbel, M.A., 2003. Chemical weathering indices applied to weathering profiles developed on heterogeneous felsic metamorphic parent rocks. Chemical Geology 202(3-4): 397- 416.

Rate, A.W., Sheikh-Abdullah, S.M., 2017. The geochemistry of calcareous forest soils in Sulaimani Governorate, Kurdistan Region, Iraq. Geoderma 289: 54-65.

Regassa, A., van Daele, K.V., De Paepe, P., Dumon, M., Deckers, J., Asrat, A., van Ranst, E., 2014. Characterizing weathering intensity and trends of geological materials in the Gilgel Gibe catchment, southwestern Ethiopia. Journal of African Earth Sciences 99(2): 568-580.

Shao, J., Yang, S., Li, C., 2012. Chemical indices (CIA and WIP) as proxies for integrated chemical weathering in China: Inferences from analysis of fluvial sediments. Sedimentary Geology 265-266: 110-120.

Şenol, H., Tunçay, T., Dengiz, O., 2018. Geochemical Mass balance applied to the study of weathering and evolution of soil. Indian Journal of Geo-Marine Sciences 47(9):1851-1865.

Taylor, S.R., McLennan, S.M., 1985. The Continental Crust: its Composition and Evolution. $3^{\text {rd }}$ Edition. Blackwell Scientific Publications, Oxford, 312p..

Vermeire, M.L., Cornu, S., Fekiacova , Z., Detienne , M., Delvaux , B., Cornélis, J.T., 2016. Rare earth elements dynamics along pedogenesis in a chronosequence of podzolic soils. Chemical Geology 446: 163-174.

Voicu, G., Bardoux, M., 2002. Geochemical behavior under tropical weathering of the Barama-Mazaruni greenstone belt at Omai gold mine, Guiana Shield. Applied Geochemistry 17(3): 321-336.

Voicu, G., Bardoux, M., Jébrak, M., Voicu, D., 1996. Normative mineralogical calculations for tropical weathering profiles. Geological Association of Canade and Mineral Association of Canadian 21: 58-69.

von Eynatten, H., Barceló-Vidal, C., Pawlowsky-Glahn, V., 2003. Modelling compositional change: The example of chemical weathering of granitoid rocks. Mathematical Geology 35(3): 231-351.

Yang, S.Y., Jung, H.S., Li, C.X., 2004. Two unique weathering regimes in the Changjiang and Huanghe drainage basins: geochemical evidence from river sediments. Sedimentary Geology 164(1-2): 19-34.

Zhou, X., Li, A., Jiang, F., Lu, J., 2015. Effects of grain size distribution on mineralogical and chemical compositions: a case study from size-fractional sediments of the Huanghe (Yellow River) and Changjiang (Yangtze River). Geological Journal 50(4): 414-433. 